\title{
NIEKOLKO POZNÁMOK K NÁMIETKE ZAUJATOSTI V TRESTNOM KONANÍ
}

\section{FEW REMARKS ON OBJECTION OF BIAS IN CRIMINAL PROCEEDINGS}

\author{
Martin Floriš ${ }^{1}$ \\ https://doi.org/10.33542/SIC2020-2-02
}

\begin{abstract}
ABSTRAKT
Právo na spravodlivé súdne konanie vedené pre nezávislým a nestranným súdom, analogicky rozšíritelné aj o rozmer nezávislosti a nestrannosti orgánov činných v trestnom konaní (s výnimkou vzt'ahov nadriadenosti a podriadenosti, o ktorej v prípade súdu ${ }^{2}$ nemožno hovorit'), je dlhodobo verejne diskutovanou témou, o aktuálnosti ktorej svedčia aj aktuálne znepokojivé zistenia o zlyhávaní nezávislosti minimálne časti súdnej moci, či (opät) minimálne individuálnych zlyhaní sudcov ako osôb, ktorých mandát má a v budúcnosti musí byt' garantom práva na spravodlivý proces. Pokial' ide o nestrannost', táto objektívne musí byt' súčast'ou právnej kultúry demokratického štátu. Pre úplnost' je však nutné dodat', že právna úprava analyzuje len stav de lege ferenda a jej skutočné pretavenie bude vždy aspon̆ čiastočne závislé od osôb vykonávatel'ov štátnej moci, čo však tomuto článku nebráni analyzovat' zákonom predpokladaný postup v prípade konania o námietke zaujatosti v trestnom konaní.
\end{abstract}

\begin{abstract}
The right to a fair trial conducted by an independent and impartial tribunal, extending by analogy to the dimension of independence and impartiality of the law-enforcement authorities (with the exception of relations of superiority and subordination, which cannot be observed in court-structures), the timeliness of which can be also confirmed by the current disturbing findings, related to the failure of the independence of at least part of the judiciary, or (again) at least the individual-observed failure of judges as persons whose mandate has and must be in future guarantor of the right to a fair trial. As far as impartiality is concerned, it must objectively be part of the legal culture of a democratic state. However, for the sake of completeness, it should be added that the legislation only analyzes the state of de lege ferenda and that its actual remittance will always be at least partly dependent on the persons executing the state power, but this fact does not prevent this article from analysing that kind of proceedings.
\end{abstract}

\section{I. ÚVOD}

Právny režim konania o námietke zaujatosti v zmysle ustanovení $\S 31$ a 32 Trestného poriadku možno propedeuticky rozdelit' do dvoch kategórií. V prvom prípade ide o konania na podklade námietky zaujatosti vznesenej priamo osobou, vystupujúcou v pozícii úradnej osoby ${ }^{3}$ a teda osobou, ktorej sa tento dôvod týka (vznesenie námietky vlastnej zaujatosti). V druhom prípade ide o konanie na podklade podania strany trestného konania. Druhá menovaná

\footnotetext{
JUDr., Mgr. PhD., Okresný súd Trnava, Slovenská republika,

District Court in Trnava, Slovak republic.

2 S výnimkou právneho názoru súdu vyššieho stupňa.

3 V danom článku použivame pre označenie osôb, o ktorých pojednáva priamo Trestný poriadok v $§ 31$ ods. 1 svojho textu sumárny pojem ,úradná osoba“, ktorý je nepochybne zjednodušením, avšak postačuje pre dosiahnutie účelu výkladu.
} 
kategória je z praktického uhla pohl’adu častejšie sa vyskytujúca a okrem realizácie procesného oprávnenia účastníka možno konštatovat', že nezriedka má aj obštrukčný charakter sledujúci účel predíženia konania. V prvom prípade môže mat' charakter preventívny (v sporných situáciách úradná osoba namietne vlastnú zaujatost's tým, že nadriadený subjekt o jej prípadnej zaujatosti rozhodne bez záväznosti jej subjektívnym postojom, avšak aj na podklade jej vyjadrenia). ${ }^{4}$ Odborná literatúra nezriedka analyzuje otázky súvisiace s námietkou zaujatosti v závislosti od postavenia úradnej osoby (tzn. zaujatosti sudcu, prokurátora, znalca a pod.). V nasledujúcich riadkoch sa zameriame najmä na predpoklady pre konštatovania zaujatosti resp. nezaujatosti, za súčasného rešpektovania rôznorodosti procesného postavenia relevantných osôb. ${ }^{5} \mathrm{~V}$ texte sa nevyhneme dôrazu na postavenie sudcu ako garanta trestného konania, pretože práve na túto osobu sú kladené najprísnejšie požiadavky na jej nestrannost'. Aj súdna prax sa v rozhodujúcej miere venuje analýze zaujatosti a nezaujatosti sudcov, pričom v prípade iných úradných osôb používa skôr primeranú úpravu (ktorú navyše možno často spojit' so široko chápanou procesnou prevenciou, ktorá by v prípade sudcu mohla byt' považovaná za odňatie práva na zákonného sudcu).

\section{NÁMIETKA ZAUJATOSTI A POSTUP PRI KONANÍ O NEJ ${ }^{6}$}

V prípade zistenia dôvodu zaujatosti, je úradná osoba povinná tento dôvod oznámit’ subjektu oprávnenému rozhodnút' o jej prípadnom vylúčení alebo neexistencii dôvodov na takýto postup; uvedenú procedúru je spravidla nevyhnutné dodržat' aj v prípade ak existuje dôvod vylúčenia ex lege, $v$ zmysle $\S 31$ ods. 2 a ods. 4 Trestného poriadku, t. j. v prípadoch existencie nevyvrátitel'nej domnienky zaujatosti. ${ }^{7}$

\section{Sudca pre prípravné konanie/samosudca/člen senátu}

V prípade sudcu alebo prísediaceho ide o senát nadriadeného súdu, v prípade člena senátu odvolacieho alebo dovolacieho súdu ide o iný senát toho istého súdu, pričom zastupovanie je riešené účinným rozvrhom práce schváleným na daný rok. ${ }^{8} \mathrm{~V}$ prípade, ak námietku zaujatosti voči sudcovi resp. členovi senátu (vrátane predsedu) vznesie strana trestného konania ${ }^{9}$ postup je pomerne odlišný, ked’že o vylúčení rozhoduje orgán, proti ktorému námietka smeruje - t. j. sudca pre prípravné konanie, samosudca alebo súd v senáte na neverejnom zasadnutí.

4 Nemožno tiež vylúčit' motiváciu k ,zbaveniu sa“ problémovej veci, ktorá je síce pochopitel'nou, avšak právne nežiadúcou motiváciou.

5 Ak nadobudne čitatel' dojem, že článok pojednáva vo zvýšenej miere o súdnej etape konania, bude to zrejme spôsobené snahou doplnit’ teoretické úvahy o praktické skúsenosti zo súdnej praxe. V článku sa však snažíme o komplexnejšie poňatie inštitútov, t.j. nielen v súdnej etape konania.

6 Trestný poriadok rozlišuje oznámenie vlastnej zaujatosti úradnej osoby a námietku zaujatosti vznesenú stranou; postup a konanie sa líši v závislosti od postavenia úradnej osoby a úpravy vzt’ahujúcej sa na toto postavenie.

7 K tomu vid’ napr.: RAJNIČ, M. - SEPEŠI, P. : Komentár k § 32 zákona č. 301/2005 Z. z. Trestný poriadok. EPI komentáre - elektronická verzia alebo RAJNIČ, M. - SEPEŠI, P.: Komentár k § 32 zákona č. 301/2005 Z. z. Trestný poriadok. Eurokódex komentár zákona č. 301/2005 Z. z, komentáre - elektronická verzia.

8 V prípade prísediacich používa zákon formuláciu ,podl'a pokynu predsedu senátu“. Ide o mätúci pojem, ked’že predseda senátu v takomto prípade určí iného prísediaceho, avšak iba zo zoznamu prísediacich príslušného senátu (okrem prípadu, ked' v konaní vystupuje náhradný prísediaci, tento inštitút nie je primárne zameraný na zaujatost' člena senátu, ide však o logickú aktivitu smerujúcu k urýchleniu konania).

9 Pojem ,strana trestného konania“ je vymedzený v ustanovení § 2 ods. 11 Trestného poriadku, v zmysle ktorého, je v konaní pred súdom stranou „, ten, proti komu sa vedie trestné konanie, poškodený, zúčastnená osoba a prokurátor; rovnaké postavenie ako strana má aj zástupca občianskeho združenia, dôveryhodná osoba, ako aj iná osoba, na ktorej návrh alebo žiadost'sa konanie vedie alebo ktorá podala opravný prostriedok a v konaní proti mladistvému aj orgán sociálnoprávnej ochrany deti a sociálnej kurately. Ak sa v tomto zákone použiva pojem strana, rozumie sa tým v predsúdnom konani aj subjekt trestného konania, ak z jednotlivého ustanovenia nevyplýva niečo iné.“ Je však nepochybné, že z hl'adiska periodicity, sú najčastejšie námietky zaujatosti podané obvineným resp. obžalovaným. 


\section{Prokurátor}

V prípade prokurátora ${ }^{10}$ rozhoduje o zaujatosti prokurátora aktuálne vykonávajúceho úkony $\mathrm{v}$ danej trestnej veci bezprostredne nadriadený prokurátor. Hoci sa uvedený pojem zdá byt' pomerne vágnym, osobitný predpis, ktorým je zákon č. 153/2001 Z. z. o prokuratúre v znení neskorších predpisov, vymedzuje bezprostredne nadriadeného prokurátora $\mathrm{v} \S 53$ ods. 1 a 2 svojho textu ${ }^{11}$, pričom aplikabilita na trestné konanie je podčiarknutá aj v odseku 3 citovaného ustanovenia. Zmienená úprava je výrazom monokratického poňatia prokuratúry v podmienkach SR; zároveň upravuje aj aspekt úpravy Európskej prokuratúry.

\section{Súdni úradníci}

V prípade oznámenia zaujatosti probačným a mediačným úradníkom, vyšším súdnym úradníkom alebo súdnym tajomníkom (alebo aj asistentom senátu), o zaujatosti týchto rozhodne predseda senátu ${ }^{12}$, t. j. rozhodnutím vydaným ex cathedra ${ }^{13}$. Podobný postup sa aplikuje aj v prípade námietky zaujatosti vznesenej stranou.

\section{Právny čakatel' prokuratúry, asistent prokurátora ${ }^{14}$ a zapisovatel'}

Ak oznámi svoju zaujatost' osoba činná v trestnej veci, kde koná prokurátor (v prípade zapisovatel'a, iba v prípade ak je činný pre prokuratúru, napr. v rámci konania o dohode o vine a treste), rozhodne o vylúčení resp. nevylúčení prokurátor, v ktorého veci sú tieto osoby činné (tzn. prokurátor vykonávajúci dozor).

Na tomto mieste je teda potrebné pozorovat', že ak sa zaujatost' netýka osoby, ktorej zákon zveruje de facto najvyššiu kompetenciu v rámci danej inštancie (t. j. predseda senátu, resp. osoba nesúca jeho postavenie, alebo dozorujúci prokurátor), je táto kompetencia zverená práve týmto osobám ako osobám nesúcim zodpovednost' za zákonnost' súdneho, resp. prípravného konania.

\section{Zapisovatel' resp. asistent senátu a technický asistent}

Ak sme vyššie poukázali na postavenie asistenta senátu, je potrebné poznamenat', že Trestný poriadok hovorí o zapisovatel'ovi a tento inštitút je nevyhnutné aplikovat' na asistenta senátu ${ }^{15}$. V prípade zaujatosti zapisovatel'a rozhoduje ten orgán, ktorý zapisovatel’a pribral, v konaní

10 Hoci to Trestný poriadok explicitne neupravuje pôjde najmä o etapu prípravného konania.

11 Bezprostredne nadriadeným prokurátorom je :

a) generálny prokurátor, ak ide o námestníka generálneho prokurátora, špeciálneho prokurátora, krajského prokurátora a prokurátora, ktorý vo funkcii národného člena zastupuje Slovenskú republiku v Eurojuste,

b) príslušný vedúci prokurátor generálnej prokuratúry, ak ide o ostatných prokurátorov generálnej prokuratúry,

c) príslušný krajský prokurátor, ak ide o prokurátora krajskej prokuratúry alebo príslušného okresného prokurátora,

d) príslušný okresný prokurátor, ak ide o prokurátora okresnej prokuratúry.

Bezprostredne nadriadeným prokurátorom prokurátora Európskej prokuratúry vo veciach patriacich do pôsobnosti Európskej prokuratúry je prokurátor Európskej prokuratúry alebo orgán Európskej prokuratúry podl'a osobitného predpisu.

12 Postavenie predsedu senátu má aj sudca pre prípravné konanie a samosudca.

13 Pôjde zrejme o uznesenie, ako v prípravnom konaní, tak aj v súdnom, resp. vykonávacom konaní.

14 Inštitút asistenta prokurátora bol do právneho poriadku SR inkorporovaný zákonom č. 220/2011 Z. Z., ktorým sa mení a dopíňa zákon č. 153/2001 Z. z. o prokuratúre v znení neskorších predpisov a ktorým sa menia a dopíňajú niektoré zákony, teda novelou zákona o prokuratúre a d’alších súvisiacich predpisov. Je potrebné dodat', že novela ostala pomerne obsolentnou, ked’že neprišlo k naplnenie stavov asistentov prokurátorov, pričom vymedzenie ich postavenia získalo zmysel až opakovaným inkorporovaním inštitútu právneho čakatel'a prokuratúry, ktorého právomoc bola vymedzená rovnako ako v prípade zamýšl’aných asistentov prokurátora.

15 Asistent resp. asistentka senátu sú pojmy, ktoré pozná zákon o súdnych úradníkoch (zákon č. 549/2003 Z. z. o súdnych úradníkoch v znení neskorších predpisov). Trestný poriadok používa pojem ,zapisovatel“ (\$27 Trestného poriadku) ako pojem všeobecnejší. Pri konaní pred súdom je potrebné postavenie zapisovatel'a vztiahnut’ aj na postavenie asistenta senátu, nakol'ko okrem činností vykonávaných mimo rámca trestného konania vykonáva aj činnosti predpokladanú Trestným poriadkom. 
pred súdom je to predseda senátu. ${ }^{16}$ Obdobné postavenie ako zapisovatel' má aj technický asistent ( $\$ 27$ Trestného poriadku).

\section{Znalec, tlmočník alebo prekladatel'}

V prípade znalca, tlmočníka alebo prekladatel'a ide o osoby zúčastňujúce sa na konaní, ktoré majú v určitom (aj ked' de facto minimálnom) rozsahu postavenie účastníka konania, hoci uvedené vymedzenie nie je explicitne uvedené $\mathrm{v}$ texte procesného predpisu trestného práva a ide skôr o aplikáciu teoretických právnych východísk na prax trestného práva. Postavenie vymenovaných subjektov je špecifické aj tým, že o ich prípadnej zaujatosti pojednáva osobitný predpis, ktorým je zákon č. 382/2004 Z. z. o znalcoch, tlmočníkoch a prekladatel'och a o zmene a doplnení niektorých zákonov v znení neskorších predpisov. V zmysle $\S 11$ ods. 2 citovaného predpisu, ak sa znalec, tlmočník alebo prekladatel' dozvie o skutočnostiach, pre ktoré je vylúčený, bezodkladne to musí oznámit' zadávatel'ovi a ak je zadávatel'om súd alebo iný orgán verejnej moci, rozhodne o jeho vylúčení tento orgán. $Z$ hl'adiska praktického prichádza do úvahy rozhodovanie o vylúčení znalca (prekladatel'a alebo tlmočníka), ktorý bol do konania pribratý orgánom činným v trestnom konaní, teda nie je dôvodné rozhodovat' o vylúčení iných znalcov (prekladatel'ov alebo tlmočníkov), ako tých, ktorí majú reálne v konaní vystupovat' a o ich ustanovení sa strany dozvedajú spravidla pri ich ustanovení. V praxi sa nezriedka stáva, že orgán činný v trestnom konaní alebo súd preventívne zist’uje, či nie je daný potenciálny dôvod zaujatosti takýchto osôb pred ich ustanovením, pričom v prípade pochybností (ked’že spravidla do úvahy prichádza väčšie množstvo osôb, či už zo zoznamu stálych znalcov alebo tzv. ad hoc znalcov, resp. tlmočníkov či predkladatel'ov) problematická osoba nie je do konania pribratá. Ak aj napriek takémuto zist'ovaniu bola ustanovená osoba, u ktorej existuje pochybnost' o jej nezaujatosti, bude potrebné postupovat' rovnako ako v prípade ustanovenia takejto osoby bez predchádzajúcej konzultácie ${ }^{17}$. Ak je teda ustanovená osoba, ktorej je známy potenciálny dôvod jej vylúčenia, táto má povinnost' túto skutočnosti oznámit' orgánu, ktorý ju ustanovil. Možnost' strán namietat' zaujatost' znalca je tiež umožnená postupom podl'a $§ 142$ ods. 3 Trestného poriadku ${ }^{18}$, pričom ,osobou znalca“ sa v tomto ohl'ade myslí aj prípadná zaujatost' resp. nezaujatost' osoby znalca; vecné dôvody potom budú znamenat' skôr možnost' namietat' vecnú správnost' položených otázok; ohl'adom procesnej ekonomiky - v tomto ohl'ade máme za to, že tento inštitút je použitel'ný iba v obmedzenej miere (napr. v prípade zjavne neúčelných rozhodnutí o pribratí takejto osoby), ked' $\mathrm{v}$ opačnom prípade by bol orgán prejednávajúci vec nútený nepriamo konat' $\mathrm{v}$ niektorých prípadoch $\mathrm{v}$ rozpore so zásadou zistenia skutkového stavu bez dôvodných pochybností (v prípade znalcov), resp. v prípade prekladatel'ov a tlmočníkov $\mathrm{v}$ rozpore so zásadou prevencie. ${ }^{19} \mathrm{~V}$ prípade tlmočníkov a predkladatel'ov, títo na rozdiel od znalcov nie sú pribratí formou uznesenia, ale formou opatrenia (t. j. formou, ktorá nepripúšt’a opravný prostriedok) a o ich zaujatosti pojednáva $§ 29$

16 V jeho postavení aj samosudca a sudca pre prípravné konanie. Uvedené ustanovenie má za dôsledok zdôraznenie skutočnosti, že o zaujatosti zapisovatel'a (asistenta senátu) rozhoduje predseda senátu a to aj v prípadoch výsluchu vedeného napr. vyšším súdnym úradníkom.

17 Je ale potrebné dodat', že v zmysle zásady procesnej ekonomiky a vybavovania vecí v primeraných lehotách, konajúci orgán nebude mat' záujem vystavovat' sa riziku výkonu procesne neefektívnych úkonov, ktoré sú nielen spôsobilé predížit' konanie, ale aj v prípade ich nesprávneho vykonania založit’ procesnú vadu, potenciálne umožňujúcu zrušenie rozhodnutia v merite veci, alebo procesne ukončujúceho konanie bez meritórneho rozhodnutia (napríklad zastavenie trestného stíhania v zmysle § 215 ods. 2 písm. b) Trestného poriadku z pohl’adu závažnosti skutku vyhodnotenej na podklade znaleckého posudku zaujatého znalca).

18 O pribratí znalca sa rozhodne uznesením. Proti uzneseniu možno podat' st'ažnost' pre vecné dôvody alebo pre osobu znalca.

19 Zásadou prevencie, vo forme v akej ju prezentujeme, máme na mysli najmä potrebu výkonu niektorých aj sporných úkonov za účelom ich zabezpečenia pre prípadné preskúmavacie konanie (odvolacie, dovolacie, konanie o st’ažnosti). Netreba tiež opomenút' fakt, že súd vychádza nielen z aktuálne platnej a účinnej právnej úpravy, ale aj aktuálneho stavu judikatúry, pričom napríklad dramatická zmena v náhl'ade na niektorý právny inštitút napr. v odvolacom konaní nie je považovaná za retroaktivitu. Preto je vhodné akceptovat' fakt, že súd vykoná aj také úkony, ktoré nebudú neprimerane zdíhavé a nákladné za účelom lepšej preskúmatel'nosti vlastného rozhodnutia. V tomto prípade nehovoríme tak ani o aspekte právnom, ako skôr metaprávnom resp. psychologickom. 
ods. 1 Trestného poriadku, ktorý však len odkazuje na citovaný zákon o znalcoch, tlmočníkoch a prekladatel'och. Výkladom tohto ustanovenia môžeme dospiet' k názoru, že súd musí rozhodnút' o vylúčení resp. nevylúčení prekladatel'a alebo tlmočníka uznesením. ${ }^{20}$

\section{Nezúčastnená osoba/figurant a odborný konzultant}

Ustanovenia Trestného poriadku ( $\$ 30$ ods. 1 až 3 citovaného predpisu) upravujú postavenie nezúčastnenej osoby resp. figuranta. V prípade nezúčastnenej osoby Trestný poriadok predpokladá absenciu pochybnosti o jej nezaujatosti vo vzt’ahu $\mathrm{k}$ prejednávanej veci alebo osobám, ktorých sa úkon priamo dotýka, $\mathrm{k}$ ich obhajcom, zákonným zástupcom a splnomocnencom alebo k orgánu činnému $\mathrm{v}$ trestnom konaní resp. súdu. Z povahy veci preto vyplýva, že takúto osobu do konania priberá orgán vykonávajúci daný úkon (napr. domovú resp. osobnú prehliadku v zmysle $\S 105$ ods. 2 Trestného poriadku). V prípade figuranta zákon takýto postup neustanovuje, pričom ale možno rozhodne z preventívnych dôvodov zvažovat' pribratie iného figuranta $\mathrm{v}$ prípade pochybnosti o jeho zaujatosti, tým skôr, že v prípade vzt'ahu figuranta k osobám napr. svedkov je možné z uvedeného dôvodu identifikovat' podstatnú vadu úkonu trestného konania a $\mathrm{z}$ tohto prameniacu jeho procesnú nepoužitel'nost'. Pôsobnost' odborného konzultanta upravuje ustanovenie $\S 151$ Trestného poriadku. Zákonná úprava explicitne nereaguje na vylúčenie odborného konzultanta, $v$ danom prípade nie je možné sa opriet' ani o judikatúru, ked'že pribratie odborného konzultanta do konania je pomerne zriedkavý postup, ktorý často nahrádza v konaní znalecké dokazovanie. Hoci zaujatost' odborných konzultantov nie je patrične zákonne ukotvená, možno s poukazom na základné zásady trestného konania odporučit' skúmanie potenciálneho dôvodu zaujatosti aj u tejto osoby v rozsahu ako sa skúma pri znalcoch. Tento názor je do istej miery analógiou, avšak nie analógiou in malam partem, a preto podl'a nášho názoru prípustnou formou analógie.

\section{DÔVODY PRE VYLÚČENIE OSÔB}

V prípade dôvodov pre vylúčenie osôb používa Trestný poriadok formuláciu ,,možno mat' pochybnost'o (ich) nezaujatosti pre (ich) pomer" k veci alebo k osobám. Je viac ako vhodné poznamenat', že absolútna väčšina rozhodnutí pojednáva o zaujatosti resp. nezaujatosti sudcu, ako pomyselného garanta zákonnosti, pričom je to spravidla osoba sudcu, ktorej riadny postup garantuje zákonnost' a spravodlivost' celého konania ${ }^{21}$. Je tiež potrebné poukázat', že Ústava SR garantuje v článku 46 ods. 1 svojho textu právo na nezávislý a nestranný súd, pričom v zmysle $\S 48$ ods. 1 svojho textu nemožno nikoho odňat' jeho zákonnému sudcovi. Tento prístup ale znamená, že garancia práva na zákonného sudcu neplatí v prípade súdneho úradníka, znalca, tlmočníka a ani v prípade prokurátora či policajta. Dôvody pre vylúčenie osoby je nutné chápat' ako taxatívne. ${ }^{22}$

V zmysle záverov judikatúry je na nestrannost' potrebné hl'adiet' $\mathrm{z}$ dvoch uhlov pohl'adu: ,zo subjektívneho hl'adiska nestrannosti, čo znamená, že je potrebné zistit' osobné presvedčenie sudcu prejednávajúceho prípad a z objektivneho hl'adiska nestrannosti, t. j. je potrebné zistit', či sú poskytnuté dostatočné záruky pre vylúčenie akejkol'vek pochybnosti v danom smere. $V$

20 Na tomto mieste si dovol'ujeme pod'akovat' recenzentom za podnetnú pripomienku. Pôvodne sme zastávali názor, že rozhodnutie o vylúčení predkladatel’a resp. tlmočníka má technicko-organizačnú povahu a preto postačuje forma opatrenia. Tento názor sme prehodnotili na podklade stanoviska recenzentov, ktorí zároveň poukázali na prípustnost' st’ažnosti a dvojinštančnost' rozhodovania o takomto vylúčení tlmočníka resp. prekladatel'a.

21 „Účelom ustanovenia o vylúčení sudcu a prísediaceho z vykonávania úkonov trestného konania v konkrétnej veci je upevňovanie dôvery účastníkov konania a verejnosti v nestrannost' postupu týchto orgánov. Preto treba zabezpečit', aby sa na rozhodovaní nepodiel’al ten sudca, ktorý má preukázatel’ne k pojednávanej veci alebo k osobám uvedeným v 31 ods. 1 Trestného poriadku taký pomer, ktorý môže objektívne vzbudit’ pochybnost' o jeho spôsobilosti rozhodovat' nestranne.“ ( uznesenie Najvyššieho súdu SR, sp. zn.: 5 Tdo 30/2008, publikované ZSP 33/2009).

22 „Ustanovenie § 31 ods. 1 TP vylučuje z vykonávania úkonov trestného konania ten orgán, u ktorého by mohli vzniknút pochybnosti o jeho nezaujatosti. Dôvody možného vzniku týchto pochybností sú stanovené taxatívne."(Zbierka stanovísk NS a rozhodnutí súdov SR 58/1994 - rozsudok NS SR zo dňa 18. 02. 1993, sp. zn.: 8 Tz 53/1992 ). 
prípade subjektívneho hl'adiska nestrannosti sa nestrannost' sudcu prezumuje ă do predloženia dôkazu o opaku“" (Piersack v. Belgicko - rozsudok ESL'P z 1. októbra 1982, podobne aj uznesenie NS SR, sp. zn.: 6 Ndt 1/2016 zo dňa 09.03.2016), resp. „Objektívna nestrannost'sa posudzuje podl'a vonkajšich objektívnych skutočností. Platí tzv. teória zdania, podl'a ktorej nestačí, že sudca je subjektívne nestranný, ale musí sa ako taký objektívne javit'v očiach strán i verejnosti. Objektívne hl'adisko je založené na existencii dostatočných záruk pre vylúčenie akejkol'vek legitímnej pochybnosti o zaujatosti sudcu. Pri objektívnej nestrannosti stačí, ak sú tu okolnosti, ktoré môžu vyvolat' pochybnosti o nestrannosti súdu. Podl'a ESL'P je potrebné , 'ist' d'alej než ako sa vec javí" (looking behind appearances). Spravodlivost' nielenže má byt' vykonaná, ona sa musí aj javit’, že je vykonaná (justice must not only be done, it must also be seen to be done) “(Delcourt v. Belgicko - rozsudok ESL'P zo 17. januára 1970, Saraiva de Carvalho v. Portugalsko zo dňa 22.04.1994, . resp. uznesenie NS SR, sp. zn.: 3 Ndt 7/2017 zo dňa 05.04.2017). V prípade subjektívneho kritéria nestrannosti je teda v zmysle záverov judikatúry prezumovaná jej existencia až do momentu rozhodnutia nadriadeného súdu, pričom ide o pretavenie požiadavky kladenej na sudcov, v maximálnej možnej miere sa odosobnit' od vnútorných okolností, spôsobujúcich pochybnost' o ich zaujatosti a až v prípade dosiahnutia istej miery potom žiadat' o vylúčenie vlastnej osoby z konania a rozhodovania v konkrétnej veci. Na prvý pohl'ad by sa mohlo zdat', že koncepcia objektívnej stránky nezávislosti je v podmienkach SR uchopená diametrálne odlišne, čo sa v plnej miere nezakladá na pravde. Práve objektívne hl'adisko (t. j. to, či sa sudca javí nestranne pre účastníkov, ale aj pre verejnost' ako celok) podlieha nielen ,zdaniu sa nezávislosti“, ale je aj existenciou dostatočnej záruky nestrannosti sudcu. Za takúto záruku sa považujeme práve úprava postavenia sudcu a záruky jeho statusu. ${ }^{23}$ Ked’že subjektívne hl'adisko je pomerne t’ažko kvantifikovatel'né (vnútorný postoj sudcu je možné reprodukovat', ale aj kapacita jednotlivcov je v tomto smere rôzna), býva práve objektívna stránka nestrannosti tou čast’ou, ktorej sa v praxi prikladá najväčší dôraz. V prípade testu objektívnej nestrannosti, konanom spravidla na podklade námietky zaujatosti vznesenej stranou v konaní, je však nevyhnutné zdôraznit', že musí íst' o patrične preukázané skutočnosti. Pritom sa nemôže jednat' o okolnosti bežného charakteru.

Okrem tvrdenia strany, ktoré samé o sebe spravidla nepostačuje, je možné uvažovat' aj o listinných dôkazoch; najčastejším dôkazom pravdivosti je potvrdenie danej skutočnosti príslušným sudcom. Do úvahy potenciálne prichádzajú aj d'alšie dôkazné prostriedky, hoci tieto možno označit' za výsostne zriedkavé. Nie je vylúčená ani požiadavka preukázat' subjektívnu stránku zaujatosti, hoci v tomto prípade je pomerne problematický výpočet možných dôkazov (v prípade subjektívnej stránky sa skôr možno stretnút' s požiadavkou podrobného popísania potenciálneho dôvodu zaujatosti osoby, o ktorej sa koná). V prípade námietky zaujatosti vznesenej stranou, táto v princípe vysloví svoj subjektívny postoj o zaujatosti úradnej osoby (najmä sudcu), o ktorej tvrdí že existujú dôvody, ktoré sa môžu javit’ ako spochybňujúce nestrannost' aj v objektívnej rovine. „Uplatnenie inštitútu $\& 30$ ods. $1 \mathrm{Tr}$. por. prichádza do úvahy len vtedy, akje existencia pomeru vzbudzujúceho pochybnost'o nezaujatosti preukázaná. Pre takýto záver nepostačuje len subjektívny, objektívnymi faktami nepodložený pocit obvineného, založený výlučne na vlastnom nestotožneni sa s možným, pre neho nepriaznivým, rozhodnutím orgánu činného v trestnom konaní, o vylúčenie ktorého ide ". ${ }^{24}$

\footnotetext{
23 Uvedomujeme si, že tento záver v zmysle medializovaných informácií o osobných a profesijných zlyhaniach súčasných a minulých sudcov z povolania vrhajú vyslovené tvrdenia do iného svetla, v akom by v podmienkach Slovenskej republiky mali fungovat'. V predmetnej veci je ale potrebné dodat', že podl'a nášho názoru už súčasná právna úprava predstavuje dostatočnú záruku nestrannosti konania, pričom ale je možné uvažovat' o d’alšom prehíbení takejto kontroly z dôvodu posilnenia dôvery v právny štát. Ak by totiž nedochádzalo k porušeniu platnej a účinnej právnej úpravy, máme za to, že ani medializované prípady by logicky nemohli nastat'. Nejde preto podl’a nášho názoru o zlyhanie inštitucionálnej úpravy, ale skôr procesu kontroly. Na tomto mieste je nevyhnutné poznamenat', že posilnenie kontroly nestrannosti sudcov od akýchkol'vek nežiaducich faktorov je prehíbením princípov právneho štátu, ale nesmie prichádzat'v takej forme, ktorá by princípy právneho štátu fakticky negovala.

24 Uznesenie Najvyššieho súdu SR z 2. 4. 2008 sp. zn. 3Tdo 9/2008.
} 
Hoci aplikovatel'nost' inej ako trestnoprávnej judikatúry na podmienky trestného práva môže byt' sporná, považujeme za vhodné súhlasit's názorom Najvyššieho súdu SR, ktorý uznesením 3Nc/4/2015 zo dňa 26.03.2015 judikoval, že je nevyhnutné predpokladat' aj u osôb sudcov uzavretie právnych vzt'ahov istého druhu (napr. zmluva o účte v banke, používaní mobilného telefónu a internetu, káblovej televízie, odoberaní vody, plynu, elektriny, o hypotekárnom úvere, o pôžičke, prípadne leasingovú zmluvu a pod.). Samotný vstup sudcu do takéhoto právne vzt’ahu nezakladá dôvod vylúčenia (a to ani v prípade, ak uzavrel zmluvy so subjektom, ktorý vystupuje $\mathrm{v}$ danom konaní ako strana). Pre účely trestného konania možno podotknút', že dôvod zaujatosti rovnako nie je daný ani v prípade, ak takýto subjekt vystupuje napr. na strane poškodeného, ked’že v prípade subjektov uzatvárajúcich hromadne tzv. spotrebitel'ské zmluvy nie je väzba medzi sudcom ako spotrebitel'om a spolukontrahentom dostatočne silná. V prípade zmluvných vzt'ahov patrične individualizovaných (napr. medzi sudcom ako prenajímatel'om nehnutel'nosti a obžalovaným ako nájomcom, bude zrejme závisiet' od okolností konkrétneho prípadu, pričom bude musiet' byt' zachovaná teória zdania sa nestrannosti sudcu, $v$ opačnom prípade musí príst' k vylúčeniu sudcu z konania a prejednávania trestnej veci).

\section{Pomer k veci}

Pomerom k prejednávanej veci možno rozumiet', určitú zainteresovanost' orgánu trestného konania na skutkoch, pre ktoré sa vedie trestné stíhanie (napr. ak orgán trestného konania, prípadne jeho príbuzní boli poškodeni konaním, pre ktoré je vedené trestné stíhanie, prípadne orgán trestného konania mohol byt' svedkom skutku, pre ktorý sa trestné stíhanie vedie a pod.). " ${ }^{25} \mathrm{~V}$ prípade pomeru $\mathrm{k}$ veci, $\mathrm{v}$ prípade jeho preukázania dochádza $\mathrm{k}$ vylúčeniu osoby bez d'alšieho dokazovania. Je potrebné dodat', že na rozdiel od pomeru k osobe, býva pomer k veci zriedkavejšie tvrdený dôvod vylúčenia osoby, avšak jeho existencia spôsobuje vylúčenie osoby častejšie $^{26}$. Za špecifický dôvod pomeru $\mathrm{k}$ veci môžeme $\mathrm{z}$ propedeutického hl'adiska chápat' aj existenciu postavenia osoby, o ktorej vylúčení sa koná v inom procesnom postavení (§ 31 ods. 2 Trestného poriadku); tento dôvod však v zmysle právnej úpravy platnej v SR je v trestnom konaní chápaný ako separátny dôvod pre vylúčenie osoby, t. j. stricto sensu sa nepokladá za pomer k veci.

\section{Pomer k osobe}

Trestný poriadok rozlišuje ako dôvod zaujatosti pomer k niektorej osobe, ktorej sa úkon trestného konania priamo dotýka alebo $\mathrm{k}$ jej obhajcovi, zákonnému zástupcovi, splnomocnencovi alebo pre pomer k inému orgánu činnému v tomto konaní. Osobou, ktorej sa úkon priamo dotýka sa rozumejú najmä strany v trestnom konaní, predovšetkým obvinený (rovnako aj obžalovaný a odsúdený), ale takouto osobou môže byt' napríklad aj poškodený, svedok, resp. teoreticky aj znalec, tlmočník, či prekladatel'. Takýmto pomerom sa rozumie predovšetkým príbuzenský ${ }^{27}$ alebo iný obdobný pomer (napr. vzt'ah druha a družky, blízky priatel'ský vzt'ah a pod.), ktorý by mohol odôvodnit' pochybnost' o nezaujatosti úradnej osoby. Takúto povahu však môže mat' aj nepriatel'ský vzt'ah, alebo vzt'ah založený na minulom konflikte. ${ }^{28}$ Súdna prax však v pomerne extenzívnej forme diferencuje pomer k osobe vzniknutý v rámci trestného konania a mimo rámca trestného konania, inými slovami vzt’ahy

25 RAJNIČ, M. - SEPEŠI, P.: Komentár k § 31 zákona č. 301/2005 Z. z. Trestný poriadok. EPI komentáre - elektronická verzia.

26 Uvedené tvrdenie opierame o poznatok, že pomer medzi sudcom a inou osobou býva spravidla vzdialenejší (týka sa skôr širšieho okruhu známych ako bezprostrednej rodiny a priatel’ov), avšak v prípade pomeru k veci je tento častejšie chápaný ako bezprostredný aspekt. Ponecháme bokom obštrukčné snahy niektorých obžalovaných, u ktorých z hladiska výskytu nachádzame skôr poukaz na pomer k osobe resp. osobám ako pomer $\mathrm{k}$ veci.

27 Nie každý príbuzenský pomer je dôvodom pre vylúčenie veci. Takýmto dôvodom napríklad nebude vzdialený príbuzenský pomer, na základe ktorého sa osoby ani nepoznajú, resp. poznajú ale nestretávajú ani spolu nekomunikujú.

28 RAJNIČ, M. - SEPEŠI, P.: Komentár k § 31 zákona č. 301/2005 Z. z. Trestný poriadok. Eurokódex komentár zákona č. 01/2005 Z. z, komentáre - elektronická verzia. 
vznikajúce vedením trestného konania súdna $\operatorname{prax}^{29}$ nepovažuje za dôvod pre vylúčenie osoby $^{30}$.

Možno konštatovat', že spôsob vedenia trestného konania osobou, predovšetkým vedenia pojednávania, výsluchu, či verejného resp. neverejného zasadnutia samosudcom, sudcom pre prípravné konanie a predsedom senátu na jednej strane a spôsob a výsledok predchádzajúceho konania (najmä predchádzajúce odsúdenie sudcom v inej veci, inom konaní, alebo v inej etape konanie, s ktorou zákon nespája vylúčenie sudcu ex lege - pozn. konanie v merite veci vylučuje sudcu z konania o návrhu na obnovu konania v zmysle $\S 397$ ods.2 Trestného poriadku, avšak nevylučuje napríklad sudcu konajúceho v merite veci, ktorý konal v prípravnom konaní ako sudca pre prípravné konania napr. o návrhu na vzatie obvineného do väzby) nie je dôvodom pre vylúčenie sudcu aj z dôvodu, že tento aspekt bol často zámienkou procesných obštrukcií, resp. býval nepochopený zo strany osôb, voči ktorým je vedené trestné stíhanie, nakol'ko títo sa cítili ukrivdení postupom súdu. Z hl'adiska účelu trestného práva by akýkol'vek iný výklad nastavil sudcom neprimerane úzky manévrovací priestor v konaní, ked’že zásadou je skúmanie postupu súdu nadriadeným súdom iba v prípade konania o opravnom prostriedku, čo býva bud' v merite veci, resp. $\mathrm{v}$ prípadoch taxatívne vymedzených $\mathrm{v}$ zákone, $\mathrm{z}$ nich najvýznamnejším sa zdá byt' konanie o väzbe obvinenej resp. obžalovanej osoby. Máme teda za to, že zákon predpokladá autonómny postup súdu v takej forme, ktorej zákonnost' možno skúmat' iba vo vymedzených prípadoch. Nie je bez právneho významu ani skutočnost', že nie každá vada konania má taký význam a povahu, že umožňuje napr. zrušit rozhodnutie súdu prvého stupňa (napr. preklep v názve obce obvineného, na poklade ktorej poštový doručovatel' vadu rozozná a doručí zásielku riadne adresátovi).

Mierne nejednoznačná situácia nastáva $\mathrm{v}$ prípade, ak konajúci sudca vystupuje $\mathrm{v}$ trestnom konaní v pozícii poškodeného $\mathrm{v}$ súvislosti s činnost'ou obvineného resp. obžalovaného v predmetnej trestnej veci (ak by išlo o pozíciu poškodeného na podklade iných skutočností, ako tých, ktoré vznikli pri prejednávaní veci, išlo by zrejme o zaujatost' z titulu pomeru $\mathrm{k}$ osobe). Fenoménom posledných rokov, najmä v prípade väzobných vecí, je zvýšená forma provokácie obvinených resp. obžalovaných vo vzt’ahu k osobám konajúcim v mene orgánov činných $\mathrm{v}$ trestnom konaní a súdov, pričom ide o rôzne druhy hrubo urážlivých podaní, ktoré rôzne oscilujú medzi snahou uvádzat' aspoň približne reálne skutočnosti, až po čisté fabulácie. Nezriedkavou motiváciou je docielit' vylúčenie konajúceho sudcu, predĺženie konania a v dôsledku aplikácie $\S 277$ ods. 5 Trestného poriadku pri zmene samosudcu alebo senátu dosiahnut' predíženie konania tak, že v dôsledku väzobných lehôt podl'a $§ 76$ ods. 6 a 7 Trestného poriadku (alebo aj § 76a Trestného poriadku) nutne musí príst' k prepusteniu z väzby. Judikatúra $\mathrm{v}$ tomto smere nie je jednotná a možno uvažovat' o posudzovaní podl'a okolností konkrétneho prípadu (pre zaujímavost' uvádzame uznesenia Krajského súdu v Trnave z 25.02.2016, sp. zn. 5 Nto 3/2016, zo 7. júla 2016, sp. zn. 6Nto 10/2016, ktorými nebol zákonný sudca z prejednávanej veci vylúčený, avšak uznesením Krajského súdu v Trnave zo dňa 18.

29 „Len skutočnost', že sudca alebo prísediaci rozhodoval v inej trestnej veci obvineného, resp. v inej jeho právnej veci, nesúvisiacej s prejednávaným prípadom, nie je dôvodom na jeho vylúčenie z vykonávania úkonov v pojednávanej veci. “ (uznesenie Najvyššieho súdu SR sp. zn.: 5 Tdo 30/2008, publikované ZSP 33/2009). , „Žaloba na ochranu osobnosti podaná obžalovaným $v$ občianskoprávnom súdnom konani proti predsedničke senátu, ktorý pojednáva trestnú vec obžalovaného, sama osebe nespĺna zákonné podmienky uvedené v § 31 ods. 1 Tr. por. na jej vylúčenie z vykonávania úkonov trestného konania v predmetnej veci. “Uznesenie KS v Nitre, sp. zn. 2 Tos 42/2010 (Zbierka rozhodnutí a stanovísk súdov SR č. 22/2011).

30 Aj podla explicitného znenia § 31 ods. 1 Trestného poriadku nie je skoršie rozhodnutie sudcu alebo senátu o obvinenom, spoluobvinenom alebo o iných obvinených, ktorých trestné činy spolu súvisia dôvodom pre vylúčenie sudcu alebo senátu. V prípade nesúvisiacich vecí možno judikatúrny výklad výkladom len privítat'. Pre úplnost' je však potrebné dodat', že námietky zaujatosti sa v praxi zo strany obhajcov vyskytujú aj napriek takejto praxi a danej úprave (k tomu vid' napr. uznesenie Špecializovaného trestného súdu zo dňa 15.04.2020, sp. zn.: PK-2T32/2019; k medializovaným informáciám bližšie KELLÖOVÁ, L.: Kauza Kuciak: Kočner namietal, že sudcovia sú voči nemu zaujatí. Neuspel. Dostupné na portáli: aktuality.sk, https://www.aktuality.sk/clanok/782215/online-kauza-kuciak-sud-kocner-zsuzsova-15-april-2020/ [cit. Dňa 08.05.2020], pričom tieto snahy pramenia z niektorých (podl’a nášho názoru prekonaných) tendencií judikatúry NS SR. 
augusta 2016, sp. zn. 5Nto 13/2016 bol rovnaký sudca vylúčený z prejednávania tej istej právnej veci, čo bolo zdôvodnené gradáciou útokov obžalovaného na zákonného sudcu a podaním trestného oznámenia sudcu na obžalovaného za prečin ohovárania podl’a $\S 373$ ods. 1 Trestného zákona). Pre úplnost' dodávame, že ani samotné podanie trestného oznámenia sudcom nie je podl'a nášho názoru dôvodom na vylúčenie sudcu, môže však byt' jedným z dôvodov, ktoré tento postup odôvodňuje. Je tiež primerane potrebné poukázat' na judikatúru vnútroštátnych súdov aj ESLP, v zmysle ktorej musí byt' miera zranitel'nosti verejného činitel'a rádovo iná ako $\mathrm{v}$ prípade ostatných osôb. Z toho podl'a nášho názoru plynie minimálne etický záväzok sudcu tolerovat' správanie obvinených a obžalovaných vo zvýšenej miere a týmto spôsobom reagovat' až v prípade neúnosnej situácie.

V zásade podobný aspekt možno pozorovat' aj v prípade vzt'ahu konajúcej osoby $\mathrm{k}$ obhajcovi, zákonnému zástupcovi, splnomocnencovi. V prípade vzt'ahu týchto osôb súdna prax zdôrazňuje, že osobné poznanie resp. pracovný či profesijný vzt'ah nie je dôvodom pre vylúčenie osoby, minimálne nie v prípade ak vzt’ah nemá „patričnú híbku“, je totiž dôvodné očakávat', že na určitom území sa budú poznat' sudcovia, obhajcovia, zástupcovia poškodených (najmä zamestnanci úradu práce, sociálnych veci a rodiny, resp. advokáti zastupujúci poškodených) a prokurátori. Známost' uvedených osôb nie je problematická, ak má výhradne profesijnú rovinu, v prípade osobnej roviny možno pozorovat' istý vývoj v nazeraní na problematiku a posun $\mathrm{k}$ potrebe redukcie vol’nočasových aktivít sudcov a zamestnancov súdov, resp. podporne aj osôb vystupujúcich v štruktúrach orgánov činných v trestnom konaní.

\section{Vylúčenie osoby rozhodujúcej v danej veci v inom stupni}

Ustanovenie $\S 31$ ods. 4 Trestného poriadku vylučuje z konania osobu (explicitne sudcu, prísediaceho, probačného a mediačného úradníka, vyššieho súdneho úradníka a súdneho tajomníka), ktorý vo veci rozhodoval v inom stupni, spravidla na súde nižšieho stupňa, pričom ale nie je vylúčené ani rozhodovanie na súde vyššie stupňa (napr. na základe dočasného pridelenia sudcu na súd vyššie stupňa alebo preradenia na súd nižšieho stupňa na základe rozhodnutia disciplinárneho senátu), pričom uvedené sa v prípade súdov týka de facto prvostupňového, odvolacieho aj dovolacieho súdu. V prípade prokurátora tento je vylúčený z rozhodovania o st'ažnosti na nadriadenom orgáne, ak napadnuté rozhodnutie vydal, alebo dal naň pokyn, resp. súhlas ${ }^{31}$. Podstatou uvedeného ustanovenia je zabezpečit', aby bola dôsledne dodržiavaná nestranná dvojstupňová kontrola meritórnych rozhodnutí súdov ${ }^{32}$, v prípade rozhodnutia iného prokurátora ide o zachovanie revízneho princípu resp. princípu dvojinštančnosti, ktorý platí vo vymedzených prípadoch aj pre rozhodnutia orgánov činných v trestnom konaní.

31 V tomto prípade zákon expresiss verbis hovorí iba o rozhodovaní na prokuratúre vyššieho stupňa; tu poukazujeme na fakt, že ustanovenie pojednáva iba o procese rozhodovanie o opravnom prostriedku t. j. nie o konaní ako celku a teda takto vymedzená zaujatost' má krátkodobý charakter. Trestný poriadok vymedzuje prípady, ked’ prokurátor vydáva súhlas k určitému úkonu (napr. súhlas pre policajta na prehliadku tela, na odber krvi alebo na iný obdobný úkon v zmysle $\S 155$ ods. 4 Trestného poriadku). V prípade pokynov nadriadeného prokurátora, tieto upravuje $\S 6$ zákona č. 153/2001 Z. z. o prokuratúre $\mathrm{v}$ znení neskorších predpisov, pričom zákon upravuje náležitosti pokynu nadriadeného prokurátora a obsahuje aj negatívne vymedzenie obsahu takéhoto pokynu. Pokyn prokurátora ako „pána“ prípravného konania vo vztahu k policajtovi upravuje Trestný poriadok na viacerých miestach (napr. § 203 ods. 2 Trestného poriadku, § 204 ods. 2 Trestného poriadku a pod.). V tejto súvislosti možno aspoň heslovite poukázat' na oprávnenie prokurátora odňat' vec policajtovi (bez limitácie prípadným dôvodom, teda uvedené možno aplikovat' aj na pochybnosti o nezaujatosti) podl’a $\S$ 230 ods. 2 písm. f) Trestného poriadku.

32 RAJNIČ, M. - SEPEŠI, P.: Komentár k § 31 zákona č. 301/2005 Z. z. Trestný poriadok. EPI komentáre - elektronická verzia. 


\section{ZÁVER}

Námietka zaujatosti a konanie o nej predstavujú pozoruhodné fenomény trestného práva, ktorých podstatou je ukotvit', zdôraznit' a zabezpečit' jeden z podstatných aspektov práva na spravodlivý proces. Je nevyhnutné dodat', že nesprávny postup pri námietke zaujatosti má závažné dôsledky, pretože je spravidla dôvodom pre zrušenie rozhodnutia z dôvodu existencie podstatnej chyby konania, ktoré napadnutým výrokom rozsudku predchádzali ( $\$ 321$ ods.1 písm. a) Trestného poriadku), pričom na existenciu takejto vady sa musí prihliadnut' aj v prípade, ak nebola odvolaním priamo vytknutá ${ }^{33}$ resp. (ak by náprava neprišla ani v odvolacom konaní, resp. vada by sa týkala postupu odvolacieho súdu) v dovolacom konaní (§ 371 ods. 1 písm. c) Trestného poriadku). Je tiež dôvodné očakávat', že v prípade vzniku takejto vady konania $\mathrm{v}$ dovolacom konaní by došlo $\mathrm{k}$ zrušeniu rozhodnutia na podklade tzv. st'ažnosti fyzickej alebo právnickej osoby ${ }^{34}$ v zmysle čl. 127 Ústavy SR. Vzhl'adom na závažnost' takýchto ustanovení je potrebné ich poznat' a v trestnom konaní na ne primerane reagovat' procesne konformným spôsobom. Hoci právna úprava platná a účinná v podmienkach SR obsahuje niekol'ko bŕzd brániacich zneužitiu tohto inštitútu, je potrebné citlivo pristupovat' aj k tomuto problému, ked'že tendencie zneuživat' tento inštitút na obštrukčné správanie osôb, voči ktorým je vedené trestné stíhanie, sú stále aktuálne a tento stav zrejme nevymizne ani v blízkej budúcnosti.

\section{KLUUČOVÉ SLOVÁ}

zaujatost' v trestnom konaní, námietka zaujatosti a konanie o nej

\section{KEY WORDS}

bias in criminal proceedings, an objection of bias and regarding procedures

\section{POUŽITÁ LITERATÚRA}

\section{Komentáre}

1. RAJNIČ, M. - SEPEŠI, P. : Komentár k § 31 zákona č. 301/2005 Z. z. Trestný poriadok. EPI komentáre - elektronická verzia. Dostupné na portáli: epi.sk, [verzia od 01.01.2019].

2. RAJNIČ, M. - SEPEŠI, P.: Komentár k § 31 zákona č. 301/2005 Z. z. Trestný poriadok. Eurokódex komentár zákona č. 301/2005 Z. z, komentáre - elektronická verzia, dostupné na portáli: epi.sk, [verzia od 01.01.2019].

3. RAJNIČ, M. - SEPEŠI, P. : Komentár k § 32 zákona č. 301/2005 Z. z. Trestný poriadok. EPI komentáre - elektronická verzia, dostupné na portáli: epi.sk, [verzia od 01.01.2019].

4. RAJNIČ, M. - SEPEŠI, P.: Komentár k § 32 zákona č. 301/2005 Z. z. Trestný poriadok. Eurokódex komentár zákona č. 301/2005 Z. z, komentáre - elektronická verzia dostupné na portáli: epi.sk, [verzia od 01.01.2019].

Súdne rozhodnutia

1. Uznesenie Najvyššieho súdu SR sp. zn.: 5 Tdo 30/2008, publikované ZSP 33/2009.

2. Rozsudok NS SR z 18. 02. 1993, sp. zn.: 8 Tz 53/1992 - Zbierka stanovísk NS a rozhodnutí súdov SR 58/1994.

3. Uznesenie Najvyššieho súdu SR z 2. 4. 2008, sp. zn. 3Tdo 9/2008.

4. Uznesenie Najvyššieho súdu SR z 26.03.2015, sp. zn.: 3Nc/4/2015.

5. Uznesenie Krajského súdu v Nitre z 24.09.2010, sp. zn. 2 Tos 42/2010 (Zbierka rozhodnutí a stanovísk súdov SR č. 22/2011, sp. zn.: Tpj 100/2010-6).

6. Uznesenie Krajského súdu v Trnave z 25.02.2016, sp. zn. 5 Nto 3/2016.

\footnotetext{
$33 \S 317$ ods. 1 Trestného poriadku.

34 V dôsledku zavedenia inštitútu trestnej zodpovednosti právnických osôb, odhliadnuc od faktu, že právnická osoba mohla vystupovat' v konaní napr. v postavení poškodeného už pred zavedením takejto úpravy.
} 
7. Uznesenie Krajského súdu v Trnave zo 7. júla 2016, sp. zn. 6Nto 10/2016.

8. Uznesenie Krajského súdu v Trnave z 18. augusta 2016, sp. zn. 5Nto 13/2016.

9. Rozsudok ESL’P Piersack v. Belgicko z 1. októbra 1982.

10. Uznesenie Najvyššieho súdu SR, z 09.03.2016, sp. zn.: 6 Ndt 1/2016.

11. Rozsudok ESL’P Delcourt v. Belgicko zo dňa 17. januára 1970.

12. Rozsudok ESL'P Saraiva de Carvalho v. Portugalsko zo dňa 22. apríla 1994.

13. Uznesenie Najvyššieho súdu SR z 05.04.2017, sp. zn.: 3 Ndt 7/2017.

14. Uznesenie Najvyššieho súdu SR z 26.03.2015, sp. zn.: 3Nc/4/2015.

Ďalšie zdroje

1. KELLÖOVÁ, L.: Kauza Kuciak: Kočner namietal, že sudcovia sú voči nemu zaujatí. Neuspel. Dostupné na portáli: https://www.aktuality.sk/clanok/782215/online-kauza-kuciak-sud-kocner-zsuzsova-15april-2020/ [cit. Dňa 08.05.2020].

\section{KONTAKTNÉ ÚDAJE AUTORA}

JUDr. Mgr. Martin Floriš, PhD.

Predseda senátu/samosudca/ sudca pre prípravné konanie

Okresný súd Trnava

Hlavná 49, 91783 Trnava

E-mail: floris.martin1@gmail.com

Tel: + 421338821511 